\title{
Antioxidant properties and global metabolite screening of the probiotic yeast
}

\section{Saccharomyces cerevisiae var. boulardii}

\author{
Suprama Datta ${ }^{1,2}$, David J. Timson ${ }^{2,3}$, Uday S. Annapure ${ }^{1^{*}}$ \\ ${ }^{1}$ Food Engineering and Technology Department, Institute of Chemical Technology (ICT), \\ Matunga, Mumbai 400 019, India. \\ ${ }^{2}$ School of Biological Sciences, Queen's University Belfast, Medical Biology Centre, 97 \\ Lisburn Road, Belfast BT9 7BL. UK. \\ ${ }^{3}$ School of Pharmacy and Biomolecular Sciences, University of Brighton, Huxley Building, \\ Lewes Road, Brighton, BN2 4GJ. UK.
}

\begin{abstract}
Corresponding author: Uday Annapure, Food Engineering and Technology Department, Institute of Chemical Technology (ICT), Matunga, Mumbai 400 019, India. Email: udayannapure@gmail.com
\end{abstract}

\begin{abstract}
BACKGROUND: Saccharomyces cerevisiae var. boulardii is the only yeast species with probiotic properties. It is considered to have therapeutic significance in gastro-intestinal disorders. In this paper, a comparative physiological study between this yeast and Saccharomyces cerevisiae (BY4742) was performed by evaluating two prominent traits of probiotic species, responses to different stress conditions and antioxidant capacity. A global
\end{abstract}

This article has been accepted for publication and undergone full peer review but has not been through the copyediting, typesetting, pagination and proofreading process, which may lead to differences between this version and the Version of Record. Please cite this article as doi: $10.1002 /$ jsfa.8147

This article is protected by copyright. All rights reserved. 
metabolite profile was also developed in order to identify which therapeutically important secondary metabolites are produced.

RESULTS: S. cerevisiae var. boulardii showed no significant difference in growth patterns but greater stress tolerance when compared with S. cerevisiae. It also demonstrated a 6-10-fold greater antioxidant potential (judged by the DPPH assay), with 70 -fold higher total phenolic content and 20-fold higher total flavonoid content in the extracellular fraction. These features were clearly differentiated by principal component analysis and further elucidated by metabolite profiling. The extracellular fraction of the S. cerevisiae var. boulardii cultures was found to be rich in polyphenolic metabolites viz. vanillic acid, cinnamic acid, phenyl ethyl alcohol (rose oil), erythromycin, amphetamine and vitamin B6 which results in the antioxidant capacity of this strain.

CONCLUSION: This study presents a new perspective of differentiating the two genetically related strains of yeast, Saccharomyces cerevisiae and Saccharomyces cerevisiae var. boulardii by assessing their metabolome fingerprints. In addition to the correlation of the phenotypic properties with the secretory metabolites of these two yeasts, the work also emphasizes the potential to exploit S. cerevisiae var. boulardii in the industrial production of these metabolites.

Keywords: Saccharomyces cerevisiae var. boulardii NCYC 3264, probiotic, Saccharomyces cerevisiae BY4742, stress-tolerance, antioxidant capacity, global metabolite profiling

\section{Introduction}

This article is protected by copyright. All rights reserved. 
Saccharomyces cervesiae var. boulardii, has been used as an adjunctive therapy for treatment of infectious gastroenteritis or in the prevention and cure of antibiotic associated diarrhea (AAD). It was isolated from the skin of lychee and mangosteen in Indochina and has gained popularity as an alternative remedy in Europe, Africa, and South America ${ }^{1,2}$ for AAD, acute diarrhea in children, traveler's diarrhea and irritable bowel syndrome ${ }^{3,4}$.

Activities of S. cerevisiae var. boulardii include modification of host-signalling pathways involved in inflammatory and non-inflammatory intestinal diseases ${ }^{5}$, inhibition of bacterial toxins and trophic effects on the intestinal mucosa ${ }^{3}$. In these studies, researchers have carried out experiments on crude extracts of S. cerevisiae var. boulardii to assess its anti-inflammatory, antitoxin ${ }^{6}$ and anti-proliferative ${ }^{7}$ properties.

However, the taxonomic characterization of S. cerevisiae var. boulardii has been controversial. Some groups have reported this yeast to be a separate species from S. cerevisiae on account of its therapeutic value, lack of ability to produce ascospores and its apparent inability to utilize galactose $^{8,9}$. Interestingly, a later study by McCullough et al reported that $S$. cerevisiae var. boulardii is capable of utilizing galactose ${ }^{10}$. Based on nuclear DNA (nDNA)-nDNA reassociation data, Cardinali and Martini located this yeast outside the sensu stricto S. cerevisiae cluster $^{11}$. On the contrary, Molnar et al found that S. cerevisiae var. boulardii and the type strains of S. cerevisiae shared the same profile in a Random Amplified Polymorphic DNA Polymerase Chain Reaction (RAPD-PCR) analysis ${ }^{12}$. However, another study was able to distinguish between the two strains using this method ${ }^{13}$. Although, McCullough et al concluded that Restriction Fragment Length Polymorphism of the PCR-amplified intergenic transcribed spacer regions (ITS1-5.8S rDNA-ITS2) was not capable of differentiating S. cerevisiae var. boulardii from S. cerevisiae ${ }^{1}$. In another study, microsatellite length polymorphism of clinical This article is protected by copyright. All rights reserved. 
isolates, laboratory strains and industrial strains of $S$. cerevisiae resulted in a distinct pattern of $S$. cerevisiae var. boulardii, which could be distinguished from S. cerevisiae ${ }^{14}$. Comparative genome hybridization $(\mathrm{CGH})$ and other physiological analyses revealed that $S$. cerevisiae var. boulardii strains differ significantly from laboratory strains of S. cerevisiae at both the genomic and physiological levels with regard to sporulation, individual chromosome and gene copy numbers, ability for pseudohyphal switching and survival at low acid $\mathrm{pH}$. The latter two features have a direct bearing on the probiotic nature of S. cerevisiae var. boulardii ${ }^{15}$.

Apart from the molecular typing techniques, the local stress responses of probiotics entering the gastrointestinal tract against factors like variations in temperature and $\mathrm{pH}$, presence of gut enzymes, bile salts and organic acids are able to distinguish the phenotypic attributes of this yeast. These responses are complex processes involving the production of number of metabolites, intermediates, proteins and enzymes at a different level or with different activity compared to those observed before stress exposure. Evidence of heat shock proteins, osmotic shock related proteins, glutathione and thioredoxin playing vital role in protection and repair of damaged cell components and induced levels of enzymes as a response of re-organised metabolic flux in response to stress exposure has been well-documented in yeast ${ }^{16}$.

While over half of the last century was spent in commercial application of S. cerevisiae var. boulardii whole yeast formulations in treatment of diarrhea, and scientific interests on its modus operandi for therapeutic use ${ }^{17}$, not much research has been channeled into exploring the presence of biomolecules such as metabolites or polypeptides and possibility of their potential industrial applications. In this study, we aimed to compare two related yeast (S. cerevisiae var. boulardii and S. cerevisiae) by characterising both the strains with particular reference to the probiotic and antioxidant properties of the former. S. cerevisiae was chosen for this comparison This article is protected by copyright. All rights reserved. 
because it is extremely well characterised biochemically and genetically. For example, the genome of this organism is essentially fully determined ${ }^{18}$. This study has also identified which biomolecules are present in the extracellular and intracellular extracts of these two yeasts.

\section{Materials and methods}

Strains, media and Chemicals

YPD broth and separate media ingredients (e.g. yeast extract, dextrose, peptone and agar) were purchased from Difco ${ }^{\mathrm{TM}}$ BD Biosciences, USA. All other chemicals and solvents were purchased from Sigma-Aldrich Co., India. S. cerevisiae var. boulardii NCYC 3264 was procured from National Collection of Yeast Cultures (NCYC, Norwich, United Kingdom). The S. cerevisiae S288c-derived laboratory strain BY4742 (MAT $\alpha$ his $3 \Delta$, leu2 $\Delta$, lys2 $\Delta$, ura3 $\Delta$ ) was a gift from Dr. Himanshu Sinha's laboratory (Department of Biological Sciences, Tata Institute of Fundamental Research, India).Culture growth conditions

Yeast starter cultures $(5 \mathrm{ml})$ were grown overnight in a rotary shaker $(200 \mathrm{rpm})$ at $30{ }^{\circ} \mathrm{C}$ in YEPD medium containing $1 \%(w / v)$ yeast extract, 2\% $(w / v)$ peptone, and $2 \%(w / v)$ glucose. Overnight cultures were diluted to $\mathrm{OD}_{600}=0.1$ and inoculated in YEPD broth filled wells in microtitre plates. Plates were incubated at $30{ }^{\circ} \mathrm{C}$ with shaking. For anaerobic growth, wells were overlaid with paraffin oil and incubated without shaking at $30{ }^{\circ} \mathrm{C}{ }^{19}$. Growth curves were generated by sampling and reading the $\mathrm{OD}_{600}$ value after every $15 \mathrm{mins}$ until the cultures reached stationary phase using Freedom Evo 75 liquid handling and robotics station (Tecan $\AA$, Switzerland) equipped with a microplate reader. The maximum specific growth rate (k) was

This article is protected by copyright. All rights reserved. 
calculated by plotting the $\mathrm{OD}_{600}$ values vs time fitted to the logistic growth equation in GraphPad Prism 6.0 (GraphPad Software Inc, CA, USA) as follows:

$\mathrm{OD}=\mathrm{OD}_{\max } \mathrm{OD}_{0} /\left(\left(\mathrm{OD}_{\max }-\mathrm{OD}_{0}\right) \exp ^{(-\mathrm{kt})}+\mathrm{OD}_{0}\right)$

Where $\mathrm{k}$ is the maximum specific growth rate constant, $\mathrm{t}$ is the time taken in the exponential phase of the growth curve, $\mathrm{OD}_{0}$ and $\mathrm{OD}_{\max }$ are the optical densities at $\mathrm{t}=0$ and $\mathrm{t}=\mathrm{t}_{\max }$ (stationary phase) respectively. The optimum doubling time $\left(t_{d}\right)$ was calculated as $t_{d}=\log _{e} 2 / k$.

In vitro stress tolerance tests mimicking gastro-intestinal environment

Yeast cultures $\left(\mathrm{OD}_{600}=1.0\right)$ were heat shocked by shifting incubation temperatures from $30^{\circ} \mathrm{C}$ to $37^{\circ} \mathrm{C}$ (normal body temperature), $39^{\circ} \mathrm{C}$ (fever condition) and $45^{\circ} \mathrm{C}$ (an extreme heat stress) in YEPD medium for $1 \mathrm{~h}$. Aliquots were collected after $0,10,20,30,40,50$ and $60 \mathrm{~min}$ of incubation and the cell viability was determined microscopically by using a Neubauer chamber and vital staining with methylene blue ${ }^{20}$. For experiments on simulated gastro-intestinal stress, overnight cultures $\left(\mathrm{OD}_{600}=1.0\right)$ were harvested by centrifugation at $3000 \mathrm{~g}$ for $5 \mathrm{~min}$, washed with distilled water once, and incubated at $37{ }^{\circ} \mathrm{C}$ for $1 \mathrm{~h}$ in (i) a simulated gastric environment constituted by an aqueous solution containing $3 \mathrm{~g} / \mathrm{L}$ pepsin $(3200-4500 \mathrm{U} / \mathrm{mg})$ and $5 \mathrm{~g} / \mathrm{L} \mathrm{NaCl}$, pH $2.0^{21}$, (ii) a simulated intestinal environment aqueous solution containing $1 \mathrm{~g} / \mathrm{L}$ pancreatin (903 U/mg) and $5 \mathrm{~g} / \mathrm{L} \mathrm{NaCl}, \mathrm{pH} 8.0$, and (iii) exponentially grown yeast cells were diluted to an $\mathrm{OD}_{600}$ of 1.0 and $5 \mu \mathrm{L}$ of this dilution was used to spot-inoculate solid YPD medium supplemented with $0.25 \%, 0.5 \%, 0.75 \%$ and $1 \% \mathrm{w} / \mathrm{v}$ concentrations of bile salts. Plates were visualized after $48 \mathrm{~h}$ at $30^{\circ} \mathrm{C}$ and $37^{\circ} \mathrm{C}$.

Preparation of cell free extract (CFE) and ethyl-acetate fraction (EAF)

This article is protected by copyright. All rights reserved. 
Sterile YPD broth $\left(\mathrm{pH} 6.5 \pm 0.2\right.$ at $\left.25^{\circ} \mathrm{C}\right)$ was inoculated with $1 \%(\mathrm{~V} / \mathrm{V})$ of the overnight grown culture of the two strains of yeast, S. cerevisiae var boulardii NCYC 3264 and S. cerevisiae BY4742 and incubated at $30{ }^{\circ} \mathrm{C}$ for $16-18 \mathrm{~h}$ approximately until the same stage of growth (mid$\log$ phase). The overnight cultures were subjected to centrifugation at $5000 \mathrm{~g}$ for $5 \mathrm{~min}$ at $4{ }^{\circ} \mathrm{C}$. The supernatant was used as the CFE for assessing the total phenolic content (TPC), total flavonoid content (TFC) and the antioxidant capacity assays. A fraction of the supernatant was also extracted using ethyl acetate at 1:3 ratio $(\mathrm{v} / \mathrm{v})$ for $3 \mathrm{~h}$ agitation followed by filtration and concentration at $50^{\circ} \mathrm{C}$ maintained in water bath for $60 \mathrm{~min}$ in vacuo using a rotavac. The dried solute was resuspended in $40 \%$ ethanol and recovered from rotavac.

Evaluation of the antioxidant potential

Total phenolic content (TPC): The total polyphenolic content was determined colorimetrically using the Folin-Ciocalteau (FC) method according to Singleton et al. ${ }^{22}$ with some modifications. The test sample $(0.5 \mathrm{ml})$ was mixed with $0.2 \mathrm{ml}$ of $\mathrm{FC}$ reagent and allowed to stand for $10 \mathrm{~min}$, then $0.6 \mathrm{ml}$ of $20 \%(\mathrm{w} / \mathrm{v})$ sodium carbonate was added and mixed. The reaction mixture was incubated at $40{ }^{\circ} \mathrm{C}$ for $30 \mathrm{~min}$. Absorbance of the reaction mixture was measured at $765 \mathrm{~nm}$ using UV/VIS spectrophotometer (Shimadzu Inc., Japan). Gallic acid was used as standard to construct the calibration curve (Pearson's correlation coefficient: $R^{2}=0.994$ ) and the total level of phenolics for each sample was expressed as milligram gallic acid equivalents per gram of extract $\left(\operatorname{mgGAE} \cdot \mathrm{g}^{-1}\right)$.

This article is protected by copyright. All rights reserved. 
Total flavonoid content (TFC): Total flavonoid content was determined by using the aluminium chloride colorimetric method as described by Willet ${ }^{23}$ with some modifications. Aqueous ethanol extracts $(0.5 \mathrm{~mL}), 10 \%(\mathrm{w} / \mathrm{v})$ aluminium chloride $(0.1 \mathrm{~mL}), 1 \mathrm{M}$ potassium acetate $(0.1$ $\mathrm{mL})$ and distilled water $(4.3 \mathrm{~mL})$ were mixed. After incubation at room temperature for $30 \mathrm{~min}$, the absorbance was measured at $415 \mathrm{~nm}$ using a using UV/VIS spectrophotometer (Shimadzu Inc., Japan). Quercetin was used as the standard and a calibration curve (Pearson's correlation coefficient: $R^{2}=0.986$ ) was constructed. Total flavonoid content was expressed as milligram quercetin equivalents per gram extract (mg QE. $\left.\mathrm{g}^{-1}\right)$.

DPPH (1,1-diphenyl-2-picrylhydrazyl) free radical scavenging ability: The hydrogen atom or electron-donation ability of the corresponding extracts was measured from the bleaching of a purple-coloured methanol solution of $\mathrm{DPPH}{ }^{24}$. The antioxidant activity of the extracts, on the basis of the scavenging activity of the stable 1,1-diphenyl-2- picrylhydrazyl (DPPH) free radical, was determined by the method described by Dan et al ${ }^{25}$ with some modifications. Briefly, an aliquot of $1 \mathrm{ml}$ of $0.1 \mathrm{mM}$ DPPH solution in ethanol and $0.5 \mathrm{ml}$ of extract were mixed. The mixture was shaken vigorously followed by incubation at room temperature for $30 \mathrm{~min}$ in the dark. The absorbance (Abs) was measured at $517 \mathrm{~nm}$. Butylated hydroxytoluene (BHT) was used as positive control and DPPH mixture without any sample served as blank. Percentage of inhibition (I \%) of DPPH radical was determined using formula as below:

$\mathrm{I} \%=\left[\mathrm{Abs}_{(\text {blank })}-\mathrm{Abs}_{(\text {sample) }}\right] / \mathrm{Abs}_{(\text {blank })} \times 100$

Trolox equivalent antioxidant capacity assay (TEAC): Experiments were carried out according to Biskup et al ${ }^{26} \cdot 2,2^{\prime}$-azinobis(3-ethylbenzothiazoline-6-sulfonic acid) diammonium salt (ABTS) This article is protected by copyright. All rights reserved. 
and potassium persulfate $\left(\mathrm{K}_{2} \mathrm{~S}_{2} \mathrm{O}_{8}\right)$ were dissolved in distilled water to prepare the ABTS radical solution with a final concentration of $7 \mathrm{mM}$ ABTS and $2.45 \mathrm{mM} \mathrm{K}_{2} \mathrm{~S}_{2} \mathrm{O}_{8}$ followed by incubation in the dark at room temperature for 12-16 $\mathrm{h}$ before use in order to produce ABTS radical $\left(\mathrm{ABTS}^{\circ+}\right)$. The solution was diluted with distilled water to an absorbance of $0.7 \pm 0.2$ at $734 \mathrm{~nm}$ prior to use. Trolox (6-hydroxy- 2,5,7,8-tetramethylchroman-2- carboxylic acid) was used as standard. Working standard concentrations from 0-20 $\mathrm{mM}$ and extracts were added to diluted ABTS $^{\circ+}$ solution and absorbance was measured 6 min after mixing at $734 \mathrm{~nm} . \mathrm{ABTS}^{\bullet+}$ radical inhibition was expressed as $\mu \mathrm{M}$ Trolox equivalent antioxidant capacity (TEAC).

\section{Global metabolite profiling}

This method was carried out according to the protocol by Villas-Bôas et al ${ }^{27}$ with slight modifications.

Sample Preparation: Yeast cultures $(5 \mathrm{ml})$ were grown under laboratory conditions (aerobic, 30 $\left.{ }^{\circ} \mathrm{C}\right)$ until mid-log phase $\left(\mathrm{OD}_{600}=0.5\right)$ were quenched with $20 \mathrm{ml}$ of $60 \%(\mathrm{v} / \mathrm{v})$ methanol - buffer (PIPES $3 \mathrm{mM}$, EDTA $3 \mathrm{mM}, \mathrm{pH} 7.0$ ) solution at $-40{ }^{\circ} \mathrm{C}$, resulting in a final methanol concentration of $50 \%(\mathrm{v} / \mathrm{v})$, followed by centrifugation at $770 \mathrm{~g}$ for $20 \mathrm{~min}$ at $-20{ }^{\circ} \mathrm{C}$ to separate the biomass. The biomass concentration was measured between $0.7-1.0 \mathrm{~g}$ cell dry weight per litre $\left(\mathrm{CDW}^{-1}\right)$. Aliquots of the supernatant were evaporated to dryness under vacuum using a vacuum centrifuge (Eppendorf ${ }^{\mathrm{TM}}$, Germany) and stored as the extracellular fraction at $-80{ }^{\circ} \mathrm{C}$ until the derivatisation step. Pellet was further treated for overall intracellular metabolite extraction i.e. amino acids, organic acids, nucleotides, peptides, sugars, sugar alcohols and sugar phosphates by chloroform : methanol : buffer (CMB) extraction ${ }^{27}$ and fatty acids by pure methanol extraction ${ }^{28}$. CMB extraction was carried out by resuspending the pellet in $5 \mathrm{ml}$ cold This article is protected by copyright. All rights reserved. 
chloroform $\left(-40^{\circ} \mathrm{C}\right)$ followed by addition of $2.5 \mathrm{ml}$ cold methanol $\left(-40^{\circ} \mathrm{C}\right)$ and $2 \mathrm{ml}$ ice-cold buffer (PIPES, $3 \mathrm{mM}$; EDTA, $3 \mathrm{mM}$; pH 7.2) sequentially under manual shaking. The suspension was agitated vigorously at 300 r.p.m on a platform shaker for $45 \mathrm{~min}$ at $4{ }^{\circ} \mathrm{C}$. Separation of the chloroform and the aqueous phase was induced by centrifugation $(770 \mathrm{~g}, 20$ $\left.\min ,-20^{\circ} \mathrm{C}\right)$. The upper aqueous phase, containing the polar metabolites from the intracellular fraction, was collected without disturbing the pellet of the cell debris on top of the lower chloroform phase (lipophilic metabolites). A second extraction step was repeated and the extract was pooled with the upper aqueous phase in order to increase the concentration of the polar metabolites. Pellet was further extracted with $2.5 \mathrm{ml}$ pure methanol followed by freezing in liquid nitrogen for $10 \mathrm{mins}$. The frozen suspension was thawed in an ice-bath and centrifuged at $770 \mathrm{~g}$ for 20 min at $-20{ }^{\circ} \mathrm{C}$. Supernatant was collected and pooled with a second extract. Extracts (supernatants) of the intracellular fractions were evaporated to dryness using a vacuum centrifuge (Eppendorf ${ }^{\mathrm{TM}}$, Germany) and stored at $-80{ }^{\circ} \mathrm{C}$ until the derivatisation step.

Derivatisation: Methyl chloroformate (MCF) - alkylation derivatisation was carried out according to Villas-Bôas et al. (2003b) ${ }^{29}$ with some modifications. Briefly, vacuum dried samples were resuspended in $\mathrm{NaOH}(200 \mu 1$ of a $1 \mathrm{M}$ solution) and mixed with $34 \mu \mathrm{l}$ of pyridine and $167 \mu 1$ of methanol, followed by addition of $20 \mu \mathrm{l} \mathrm{MCF}$ and vortexed for $30 \mathrm{~s}$ carried out twice. Chloroform $(400 \mu \mathrm{l})$ was added to the mixture to separate the MCF derivatives. After vigorous mixing, $\mathrm{NaHCO}_{3}(400 \mu 1$ of $50 \mathrm{mM})$ was added to partition the aqueous layer. Upper aqueous layer was discarded and the chloroform phase was subjected to GC-MS analysis.

GC-MS Analysis: Samples were analyzed on a Varian 450 gas chromatograph equipped with a Varian 220 mass spectrometer (ion trap), using a VF-5MS capillary column $(30 \mathrm{~m} \times 0.25 \mathrm{~mm}$ thick, $0.25 \mathrm{~mm}$ ). Helium was used as mobile phase at $1.0 \mathrm{ml} \mathrm{min}{ }^{-1}$, with a splitless injection This article is protected by copyright. All rights reserved. 
volume of $1.0 \mu \mathrm{l}$ at $200{ }^{\circ} \mathrm{C}$, a transfer liner at $220^{\circ} \mathrm{C}$ and an ion trap at $150{ }^{\circ} \mathrm{C}$. The mass spectrometer was operated in SCAN mode from 45 to $650 \mathrm{~m} / \mathrm{z}$. The column temperature was initially held at $45{ }^{\circ} \mathrm{C}$ for $2 \mathrm{~min}$. Thereafter, the temperature was raised with a gradient of $9{ }^{\circ} \mathrm{C}$ $\min ^{-1}$ until it reached $180^{\circ} \mathrm{C}$. This temperature was held for $5 \mathrm{~min}$. Next, the temperature was raised with a gradient of $40{ }^{\circ} \mathrm{C} \min ^{-1}$ until it reached $220{ }^{\circ} \mathrm{C}$. The temperature was again held for 5 min. Finally, the temperature was raised with a gradient of $40{ }^{\circ} \mathrm{C} \mathrm{min}^{-1}$ until it reached $240{ }^{\circ} \mathrm{C}$, which was held for 11.5 min. Data handling was carried out using WORKSTATION, Version 6.9.1 software equipped with National Institute of Standards \& Technology (NIST) mass spectrum (MS) database. The metabolites were identified using the MS database.

\section{Statistical analysis}

Univariate analyses were conducted using GRAPHPAD PRISM 6.0 (GraphPad Software Inc, CA, USA) for Windows. Analysis of Variance (ANOVA) and Pearson's correlation coefficients were performed to compare the data. All determinations were done at least in triplicate and were reported as means. The confidence limits used in this study were based on $95 \%(p<0.05)$. Principal component analysis (PCA) was performed using SPSS Statistics 20 (IBM Corporation, USA) for data processing and STATISTICA 7.1 (Dell Inc., USA) for output.

\section{Results and discussion}

The two strains show similar growth patterns under laboratory and simulated in vivo conditions

The growth curves of the organisms tested under normal laboratory conditions $\left(30^{\circ} \mathrm{C}\right.$, aerobic) and at simulated in-vivo temperature and oxygen availability $\left(37^{\circ} \mathrm{C}\right.$, anaerobic) are shown in Figure 1. Both the yeast strains showed no significant difference in growth rates under the two This article is protected by copyright. All rights reserved. 
conditions (Table 1) although the maximum optical density values $\left(\mathrm{OD}_{\max }\right)$ were significantly different between the strains under both conditions (Table 1). The optimum doubling times $\left(t_{d}\right)$ were measured at the period of maximum growth rate $(\mathrm{k})$. The similar growth kinetics pattern of both the yeasts possibly explains why neither strain is able to colonise as a permanent part of the gut flora in healthy individuals and is eliminated from the system within 3-5 days after its oral administration is discontinued ${ }^{30}$. The growth assessment of the two strains aided in deciding the sampling time points for attaining certain biomass level before carrying out the metabolome experiments in the later part of this study.

S. cerevisiae var. boulardii is more stress tolerant than S. cerevisiae

S. cerevisiae var boulardii NCYC 3264 and S. cerevisiae BY4742 showed significant difference in percentage viability upon heat treatment for $1 \mathrm{~h}$ at $37^{\circ} \mathrm{C}(\mathrm{p}$ value $=0.0078)$ and $39^{\circ} \mathrm{C}(\mathrm{p}$ value $=0.0051)$. Greater resistance was observed when compared to that of $S$. cerevisiae at both temperatures (Figure 2a, b). However, both the strains showed comparable decrease overtime with a $57.6 \%$ final viability for S. cerevisiae var. boulardii NCYC 3264 and $50.3 \%$ for $S$. cerevisiae BY4742 at $45^{\circ} \mathrm{C}(\mathrm{p}$ value $=0.0141)($ Figure $2 \mathrm{c})$. Viability levels under simulated gastric environment $(\mathrm{pH} 2.0)$ were indistinguishable for the first $10 \mathrm{~min}$, but after $15 \mathrm{~min}, \mathrm{~S}$. cerevisiae var boulardii NCYC 3264 appeared to be more resistant, maintaining its cell viability at about $57.6 \%$ with S. cerevisiae BY4742 falling to about $32 \%$ after $60 \min (p$ value $=0.0037$ ) (Figure 2d). Exposure to the simulated intestinal environment $(\mathrm{pH} 8.0)$ showed a slight difference in percentage viability $(\mathrm{p}$ value $=0.0419)$ for both the strains with a final value of $39 \%$ and $32.3 \%$ for S. cerevisiae var boulardii NCYC 3264 and S. cerevisiae BY4742 respectively (Figure 2e). S. cerevisiae var boulardii NCYC 3264 also exhibited a higher This article is protected by copyright. All rights reserved. 
tolerance than S. cerevisiae BY4742 for the bile tolerance assay (Figure 3). Studies with Bifidobacterium spp. probiotic strains show resistance to cholate concentration from 0.125 to $1.2 \%{ }^{31}$. Other published literature suggest $0.3 \%$ as the minimum concentration to define an organism as resistant to bile salts ${ }^{32}$ and the majority of yeast species grow in the presence of $0.75 \%$ bile salts. This study partly conforms with these observations with a sensitivity of $S$. cerevisiae var boulardii NCYC 3264 at $1 \%$ cholate concentration at both $30^{\circ} \mathrm{C}$ and $37^{\circ} \mathrm{C}$ but $S$. cerevisiae BY4742 being sensitive to $0.5 \%$ cholate at both the temperatures (Figure 3). Interestingly, a counter observation was made by Fietto et al with no impact on cell viability of both $S$. cerevisiae var boulardii and $S$. cerevisiae by the simulated intestinal environment and both the strains showing sensitivity to bile salt concentrations more than $0.1-0.15 \%{ }^{33}$. This study did not specify the growth stage studied (and it is not clear which growth stage, if any, most closely recapitulates the prevalent phase in the mammalian gut) whereas our study used mid-log phase cells. Potential differences such as this in the experimental procedures might account for the apparent discrepancy in the results.

\section{S. cerevisiae var boulardii demonstrates antioxidant potential}

The TPC of cell free extracts (CFE) and ethyl acetate fractions (EAF) of S. cerevisiae var boulardii NCYC 3264 were found to be significantly higher ( 70 fold) than those of $S$. cerevisiae BY4742 (Table 2). A similar pattern was observed for the DPPH radical scavenging activity with the percentage inhibition of the DPPH radical in the order of BHT (control) $>$ CFE of S. cerevisiae var boulardii $>$ EAF of $S$. cerevisiae var boulardii $>$ CFE of S. cerevisiae $>$ EAF of S. cerevisiae (Table 2). The total flavonoid content for both the extracts of S. cerevisiae var boulardii were $\sim 20$-fold higher than that of S. cerevisiae BY4742 (Table 2). The TEAC values This article is protected by copyright. All rights reserved. 
were also higher in case of $S$. cerevisiae var boulardii with no detectable activity for both the extracts of S. cerevisiae (Table 2). The data suggests that S. cerevisiae var boulardii has broad antioxidative properties. In this study, ethyl acetate extraction of cultures was carried out as a means to generate polyphenol-rich fractions having bioactivities which could be attributed to their antioxidant properties ${ }^{34,35}$. A study by Pu et al also reported EAF of plant extracts as the fraction to demonstrate highest antioxidant activity ${ }^{36}$. However, there was no significant difference between the activities shown by the CFE and EAF of S. cerevisiae var boulardii in this study.

Multivariate analysis distinguished between S. cerevisiae var. boulardii and S. cerevisiae

Principal component analysis was employed as a means of multivariate analysis in a reduced dimensional scaling approach to identify global similarities and differences between the two strains of S. cerevisiae var. boulardii NCYC 3264 and S. cerevisiae BY4742 under two different conditions (aerobic, $30{ }^{\circ} \mathrm{C}$ and anaerobic, $37{ }^{\circ} \mathrm{C}$ ). The inter-relationship among the growth kinetic, probiotic and antioxidant attributes i.e. doubling time $\left(\mathrm{t}_{\mathrm{d}}\right)$, maximum specific growth rate constant $(\mathrm{k})$, viability response under heat $\left(37^{\circ} \mathrm{C}, 39^{\circ} \mathrm{C}\right.$ and $\left.45^{\circ} \mathrm{C}\right)$, simulated gastric $(\mathrm{pH} 2.0)$, intestinal ( $\mathrm{pH} 8.0)$ and bile salt $(0.5 \% \mathrm{w} / \mathrm{v})$ stress and antioxidant capacity (TPC, TFC and DPPH radical scavenging activity), were also considered as variables in the analysis. A two-component construct of all the variables demonstrating a cumulative $92.97 \%$ of the total variance based on the eigenvalues of correlation matrix of all the components (Supplementary Table S1; Supplementary Figure S1) is illustrated in Figure 4 and Table 3. The first (PC1) and second (PC2) principal components represent $73.62 \%$ and $19.35 \%$ of the total variance respectively. Figure $4 \mathrm{a}$ and $4 \mathrm{~b}$ depict the projection of the attributes (variables) and strains under different This article is protected by copyright. All rights reserved. 
conditions (cases) respectively. A clear separation of the probiotic and antioxidant attributes represented as a cluster along the $\mathrm{X}$-axis from the growth kinetic parameters along the $\mathrm{Y}$-axis was achieved (Figure $4 \mathrm{a}$ and Table $3 \mathrm{a}$ ). The proximity of $\mathrm{S}$. cerevisiae var. boulardii to the probiotic and antioxidant cluster (Figure $4 \mathrm{~b}$ and Table $3 \mathrm{~b}$ ) clearly differentiates the strain from $S$. cerevisiae which is shown to be away from the cluster and hence negatively correlated with these two particular attributes. Thus, the two strains were well differentiated in the PCA supporting the general conclusion that they have different antioxidant profiles.

\section{Global metabolite profiling revealed antioxidant molecules}

A total of 22 metabolites in the extracellular and 18 metabolites in the intracellular fractions were identified in S.cerevisiae var boulardii NCYC 3264 (Table 4a) and seven metabolites in the extracellular and 35 metabolites in the intracellular fractions were identified in S. cerevisiae BY4742 (Table 4b) using a semi-qualitative analysis based on their fragmentation pattern in mass-spectroscopy (MS) and chromatographic retention time $\left(\mathrm{R}_{\mathrm{t}}\right)$. The extracellular fraction of S.cerevisiae var boulardii NCYC 3264 demonstrated the presence of aromatic metabolites like phenyl ethyl alcohol (orange oil), mephaneine, cymene, hydroxycinnamic acid, cinnamic acid, naphthalenol (golden yellow), quinoline, erythromycin, vanillic acid and vitamin B6 in addition to the tricarboxylic acid cycle (TCA) metabolites such as succinate, acetate, citrate ${ }^{37-39}$ and other central carbon metabolites such as amino acids and sugars (Table 4a). The intracellular fraction, on the other hand, contained largely intermediary central carbon metabolites (Table 4a). The extracellular fraction of S. cerevisiae BY4742 showed mostly TCA cycle organic acids such as citric acid, succinic acid, malic acid and fumaric acid along with lactic acid, glycerol and Dglucose, which was present as the substrate in growth media (Table 4b). The intracellular metabolites identified were proteinogenic and non-proteinogenic amino acids, organic acids, This article is protected by copyright. All rights reserved. 
sugars, and phosphorylated sugars representing key parts of central metabolism (Table 4b). However, most of the intracellular metabolites identified for both the yeasts were in the low abundance region of the chromatogram suggesting a possible loss due to leakage of metabolites during sampling or insufficient cell biomass at the start of experiment ${ }^{40}$. This study showed clear differences in the extracellular and intracellular metabolomes between the two yeasts with an abundance of aromatic metabolites in the extracellular fraction of S.cerevisiae var. boulardii NCYC 3264. The smaller number of central carbon metabolites in the intracellular fraction of S.cerevisiae var. boulardii NCYC 3264 when compared with S.cerevisiae BY4742 might be explained by the masking of weak intensity signals generated by the low concentrations of these metabolites in presence of higher concentrations of organic, inorganic acid and aromatic metabolites in the system. There was some overlap in the metabolites across the two metabolomes and between both the strains (Table 4). Some of this commonality between the extracellular and intracellular metabolite fractions may be partly due to the metabolic overflow 41, 42 . The pool of aromatic metabolites in the extracellular fraction of S.cerevisiae var. boulardii NCYC 3264 reflects the possibility of different role of these metabolites in this environment than inside the cell. A similar finding was reported by Granucci et al in S. cerevisiae CEN.PK113-7D strain where they speculated the extracellular medium as a storage place for some metabolites with roles other than central metabolism of the cell e.g. cell-to-cell communication, metabolic regulation and detoxification ${ }^{42}$. The presence of these compounds accounts for the antioxidative and probiotic property exhibited by S.cerevisiae var. boulardii NCYC 3264. However, it remains unclear what the benefits of producing such a large range of antioxidant molecules to this strain are. Nevertheless, the data indicate the possibility of exploring the potential of producing these metabolites on a larger, industrial scale from this strain.

This article is protected by copyright. All rights reserved. 


\section{Conclusions}

This study addressed the characterization of S. cerevisiae var. boulardii NCYC 3264 in comparison with $S$. cerevisiae with respect to probiotic and antioxidant properties. The two strains are markedly different in these properties, despite close genetic similarities. Based on this dataset, a global screening of the metabolite profiles was performed for the two strains which revealed a variety of polyphenolic metabolites e.g. vanillic acid, cinnamic acid, phenyl ethyl alcohol, erythromycin and pyridoxine (vitamin B6). Many of these compounds have antioxidant properties and are likely to contribute to the previously reported probiotic nature of $S$. cerevisiae var boulardii. In addition, some have potential commercial significance as fragrances, aroma and flavour compounds in food and cosmetic industries in addition to their therapeutic value. For example, vanillic acid has been associated with a number of pharmacological activities (such as inhibiting snake venom ${ }^{43,44}$, hepatoprotective activity ${ }^{45}$ and apoptosis ${ }^{46,47}$ ) but its main application is for its pleasant creamy odour and taste leading to its widespread use in fragrances and licensing as a food additive (FAO/WHO Expert Committee on Food Additives, JECFA no. 959). Cinnamic acid is used mainly in manufacturing methyl, ethyl, and benzyl esters for the perfume and flavour industry and is a precursor molecule for manufacturing sweetener aspartame via enzyme-catalysed amination to phenylalanine ${ }^{48}$. Phenyl ethyl alcohol or rose oil (PEA) is an aromatic alcohol used as an ingredient in favour and perfumery particularly where the aroma of rose is desired ${ }^{49}$. There have been reports on production of PEA from a thermotolerant strain of S. cerevisiae (Ye9-612), highlighting the commercial potential of this metabolite ${ }^{50}$. Erythromycin is a potent 14-membered macrolide antibiotic active against pathogenic Grampositive bacteria ${ }^{51,52}$. Pyridoxine (vitamin B6) is manufactured as oral supplements in the pharmaceutical sector which is necessary for the activation of glycine in the initial stages of heme production in vivo ${ }^{53}$ and is prescribed to treat a number of illnesses and deficiency This article is protected by copyright. All rights reserved. 
symptoms such as sickle-cell anemia and nervous disorders like Carpal-Tunnel syndrome ${ }^{54-56}$. The detection of these bioactive compounds in the metabolite fingerprints of the extracellular metabolome of S. cerevisiae var. boulardii suggests the possibility of using the strain for industrial scale production of these metabolites. However, before the viability of this can be fully assessed an in-depth biochemical study to elucidate the pathways (including key enzymes and intermediates) is required. Taken together, this study paves the path to understanding why $S$. cerevisiae var. boulardii is physiologically and metabolically different from baker's yeast in spite of its similar genetic make-up and provides a useful "baseline" for the assessment of any potentially probiotic yeasts discovered in the future. The data may also be useful in comparative studies between the various commercial preparations of S. cerevisiae var. boulardii which are sold worldwide allowing an assessment of the effects of formulation, storage etc on their probiotic properties.

\section{Acknowledgements}

This project was funded by University Grants Commission, India as a doctoral studentship to Suprama Datta (Sr. No. 2061130941). The work was also supported by grants from Commonwealth Scholarship Commission in the UK (reference: INCN-2014-46). We thank Dr. Himanshu Sinha (Department of Biological Sciences, TIFR, Mumbai) for access to liquid handling and robotics station for the growth kinetics studies. We thank Dr. Snehasis Chakraborty, Anuradha Deorukhkar, Sonal Patil and Ashish Waghmare (Department of Food Engineering and Technology, ICT, Mumbai) for help and advice with the multivariate analysis.

This article is protected by copyright. All rights reserved. 


\section{References}

1. McCullough MJ, Clemons KV, McCusker JH and Stevens DA, Species Identification and Virulence Attributes of Saccharomyces boulardii (nom. inval.). Journal of clinical microbiology 36:2613-2617 (1998).

2. Penna FJ, Filho LA, Calcado AC, Junior HR and Nicolli JR, [Up-to-date clinical and experimental basis for the use of probiotics]. Jornal de pediatria 76 Suppl 1:S209-217 (2000).

3. Im E and Pothoulakis $\mathrm{C}$, The intestinal microbiota: Equilibrium and disordersRecent advances in Saccharomyces boulardii research. Gastroentérologie Clinique et Biologique 34:S62-S70 (2010).

4. Gareau MG, Sherman PM and Walker WA, Probiotics and the gut microbiota in intestinal health and disease. Nature reviews Gastroenterology \& hepatology 7:503-514 (2010).

5. Czerucka D and Rampal P, Experimental effects of Saccharomyces boulardii on diarrheal pathogens. Microbes and infection / Institut Pasteur 4:733-739 (2002).

6. Pothoulakis C, Review article: Anti-inflammatory mechanisms of action of Saccharomyces boulardii. Alimentary pharmacology \& therapeutics 30:826-833 (2009).

7. Chen X, Fruehauf J, Goldsmith JD, Xu H, Katchar KK, Koon H-W, Zhao D, Kokkotou EG, Pothoulakis C and Kelly CP, Saccharomyces boulardii Inhibits EGF Receptor Signaling and Intestinal Tumor Growth in Apc(min) Mice. Gastroenterology 137:914-923 (2009).

8. McFarland LV, Saccharomyces boulardii is not Saccharomyces cerevisiae. Clinical infectious diseases : an official publication of the Infectious Diseases Society of America 22:200201 (1996).

9. Mitterdorfer G, Kneifel W and Viernstein H, Utilization of prebiotic carbohydrates by yeasts of therapeutic relevance. Letters in applied microbiology 33:251-255 (2001).

This article is protected by copyright. All rights reserved. 
10. McCullough MJ, Clemons KV, McCusker JH and Stevens DA, Species identification and virulence attributes of Saccharomyces boulardii (nom. inval.). Journal of clinical microbiology 36:2613-2617 (1998).

11. Cardinali G and Martini A, Electrophoretic Karyotypes of Authentic Strains of the Sensu Stricto Group of the Genus Saccharomyces $\dagger$. International Journal of Systematic and Evolutionary Microbiology 44:791-797 (1994).

12. Molnar O, Messner R, Prillinger H, Stahl U and Slavikova E, Genotypic Identification of Saccharomyces Species using Random Amplified Polymorphic DNA Analysis. Systematic and Applied Microbiology 18:136-145 (1995).

13. Mitterdorfer G, Mayer HK, Kneifel W and Viernstein H, Clustering of Saccharomyces boulardii strains within the species S. cerevisiae using molecular typing techniques. Journal of Applied Microbiology 93:521-530 (2002).

14. Hennequin C, Thierry A, Richard GF, Lecointre G, Nguyen HV, Gaillardin C and Dujon B, Microsatellite typing as a new tool for identification of Saccharomyces cerevisiae strains. Journal of clinical microbiology 39:551-559 (2001).

15. Edwards-Ingram L, Gitsham P, Burton N, Warhurst G, Clarke I, Hoyle D, Oliver SG and Stateva L, Genotypic and physiological characterization of Saccharomyces boulardii, the probiotic strain of Saccharomyces cerevisiae. Applied and environmental microbiology 73:24582467 (2007).

16. Estruch F, Stress-controlled transcription factors, stress-induced genes and stress tolerance in budding yeast. FEMS Microbiology Reviews 24:469-486 (2000).

17. Łukaszewicz M, Saccharomyces cerevisiae var. boulardii - Probiotic Yeast. Prof. Everlon Rigobelo (Ed.) InTech (2012).

This article is protected by copyright. All rights reserved. 
18. Goffeau A, Barrell BG, Bussey H, Davis RW, Dujon B, Feldmann H, Galibert F, Hoheisel JD, Jacq C, Johnston M, Louis EJ, Mewes HW, Murakami Y, Philippsen P, Tettelin H and Oliver SG, Life with 6000 genes. Science (New York, NY) 274:546, 563-547 (1996).

19. Pawar V, Jingjing L, Patel N, Kaur N, Doetsch PW, Shadel GS, Zhang H and Siede W, Checkpoint kinase phosphorylation in response to endogenous oxidative DNA damage in repairdeficient stationary-phase Saccharomyces cerevisiae. Mechanisms of ageing and development 130:501-508 (2009).

20. Mills DR, DIFFERENTIAL STAINING OF LIVING AND DEAD YEAST CELLS. Journal of Food Science 6:361-371 (1941).

21. Charteris WP, Kelly PM, Morelli L and Collins JK, Development and application of an in vitro methodology to determine the transit tolerance of potentially probiotic Lactobacillus and Bifidobacterium species in the upper human gastrointestinal tract. Journal of applied microbiology 84:759-768 (1998).

22. Singleton VL, Orthofer R and Lamuela-Raventós RM, [14] Analysis of total phenols and other oxidation substrates and antioxidants by means of folin-ciocalteu reagent, in Methods in enzymology. Academic Press, pp 152-178 (1999).

23. Willett WC, Balancing life-style and genomics research for disease prevention. Science (New York, NY) 296:695-698 (2002).

24. Gulluce M, Sahin F, Sokmen M, Ozer H, Daferera D, Sokmen A, Polissiou M, Adiguzel A and Ozkan H, Antimicrobial and antioxidant properties of the essential oils and methanol extract from Mentha longifolia L. ssp. longifolia. Food Chemistry 103:1449-1456 (2007).

25. Dan Y, Lee WC, Mahmud R, Pillai S, Perumal S and Ismail S, 3rd International Conference on Biotechnology and Food Science (ICBFS 2012), April 7-8, 2012Antioxidant Activities of Essential Oil of Psidium Guajava L. Leaves. APCBEE Procedia 2:86-91 (2012). This article is protected by copyright. All rights reserved. 
26. Biskup I, Golonka I, Gamian A and Sroka Z, Antioxidant activity of selected phenols estimated by ABTS and FRAP methods. Postepy higieny i medycyny doswiadczalnej (Online) 67:958-963 (2013).

27. Villas-Boas SG, Hojer-Pedersen J, Akesson M, Smedsgaard J and Nielsen J, Global metabolite analysis of yeast: evaluation of sample preparation methods. Yeast (Chichester, England) 22:1155-1169 (2005).

28. Maharjan RP and Ferenci T, Global metabolite analysis: the influence of extraction methodology on metabolome profiles of Escherichia coli. Analytical biochemistry 313:145-154 (2003).

29. Villas-Boas SG, Delicado DG, Akesson M and Nielsen J, Simultaneous analysis of amino and nonamino organic acids as methyl chloroformate derivatives using gas chromatography-mass spectrometry. Analytical biochemistry 322:134-138 (2003).

30. Kelesidis T and Pothoulakis C, Efficacy and safety of the probiotic Saccharomyces boulardii for the prevention and therapy of gastrointestinal disorders. Therapeutic advances in gastroenterology 5:111-125 (2012).

31. Ruiz L, Margolles A and Sánchez B, Bile resistance mechanisms in Lactobacillus and Bifidobacterium. Frontiers in Microbiology 4:396 (2013).

32. Gilliland SE, Staley TE and Bush LJ, Importance of bile tolerance of Lactobacillus acidophilus used as a dietary adjunct. Journal of dairy science 67:3045-3051 (1984).

33. Fietto JL, Araujo RS, Valadao FN, Fietto LG, Brandao RL, Neves MJ, Gomes FC, Nicoli JR and Castro IM, Molecular and physiological comparisons between Saccharomyces cerevisiae and Saccharomyces boulardii. Canadian journal of microbiology 50:615-621 (2004).

This article is protected by copyright. All rights reserved. 
34. Garcia-Salas P, Morales-Soto A, Segura-Carretero A and Fernandez-Gutierrez A, Phenolic-compound-extraction systems for fruit and vegetable samples. Molecules (Basel, Switzerland) 15:8813-8826 (2010).

35. Oboh G RJ, Antioxidant in Foods: A New Challenge for Food Processors. Nova Science Publishers Inc., New York, US (2007).

36. $\mathrm{Pu} \mathrm{W,} \mathrm{Wang} \mathrm{D} \mathrm{and} \mathrm{Zhou} \mathrm{D,} \mathrm{Structural} \mathrm{Characterization} \mathrm{and} \mathrm{Evaluation} \mathrm{of} \mathrm{the}$ Antioxidant Activity of Phenolic Compounds from Astragalus taipaishanensis and Their Structure-Activity Relationship. Scientific Reports 5:13914 (2015).

37. Sigler K, Knotkova A, Paca J and Wurst M, Extrusion of metabolites from baker's yeast during glucose-induced acidification. Folia microbiologica 25:311-317 (1980).

38. Stoppani AO, De Favelukes SL and Conches L, Formation of succinic acid in baker's yeast through the citric acid cycle. Archives of biochemistry and biophysics 75:453-464 (1958).

39. Wurst M, Sigler K and Knotkova A, Gas chromatographic determination of extracellular metabolites produced by baker's yeast during glucose-induced acidification. Folia microbiologica 25:306-310 (1980).

40. Smart KF, Aggio RB, Van Houtte JR and Villas-Boas SG, Analytical platform for metabolome analysis of microbial cells using methyl chloroformate derivatization followed by gas chromatography-mass spectrometry. Nature protocols 5:1709-1729 (2010).

41. Giardina BJ, Stanley BA and Chiang H-L, Glucose induces rapid changes in the secretome of Saccharomyces cerevisiae. Proteome Science 12:9-9 (2014).

42. Granucci N, Pinu FR, Han T-L and Villas-Boas SG, Can we predict the intracellular metabolic state of a cell based on extracellular metabolite data? Molecular BioSystems 11:32973304 (2015).

This article is protected by copyright. All rights reserved. 
43. Dhananjaya BL, Nataraju A, Raghavendra Gowda CD, Sharath BK and D'Souza CJ, Vanillic acid as a novel specific inhibitor of snake venom 5'-nucleotidase: a pharmacological tool in evaluating the role of the enzyme in snake envenomation. Biochemistry Biokhimiia 74:13151319 (2009).

44. Dhananjaya BL, Nataraju A, Rajesh R, Raghavendra Gowda CD, Sharath BK, Vishwanath BS and D'Souza CJ, Anticoagulant effect of Naja naja venom 5'nucleotidase: demonstration through the use of novel specific inhibitor, vanillic acid. Toxicon : official journal of the International Society on Toxinology 48:411-421 (2006).

45. Itoh A, Isoda K, Kondoh M, Kawase M, Kobayashi M, Tamesada M and Yagi K, Hepatoprotective effect of syringic acid and vanillic acid on concanavalin a-induced liver injury. Biological \& pharmaceutical bulletin 32:1215-1219 (2009).

46. Huang SM, Chuang $\mathrm{HC}, \mathrm{Wu} \mathrm{CH}$ and Yen GC, Cytoprotective effects of phenolic acids on methylglyoxal-induced apoptosis in Neuro-2A cells. Molecular nutrition \& food research 52:940-949 (2008).

47. Huang SM, Hsu CL, Chuang HC, Shih PH, Wu CH and Yen GC, Inhibitory effect of vanillic acid on methylglyoxal-mediated glycation in apoptotic Neuro-2A cells. Neurotoxicology 29:1016-1022 (2008).

48. Garbe D, Cinnamic Acid, in Ullmann's Encyclopedia of Industrial Chemistry. WileyVCH Verlag GmbH \& Co. KGaA (2000).

49. Fahlbusch K-G, Hammerschmidt F-J, Panten J, Pickenhagen W, Schatkowski D, Bauer K, Garbe D and Surburg H, Flavors and Fragrances, in Ullmann's Encyclopedia of Industrial Chemistry. Wiley-VCH Verlag GmbH \& Co. KGaA (2000).

This article is protected by copyright. All rights reserved. 
50. Eshkol N, Sendovski M, Bahalul M, Katz-Ezov T, Kashi Y and Fishman A, Production of 2-phenylethanol from L-phenylalanine by a stress tolerant Saccharomyces cerevisiae strain. Journal of applied microbiology 106:534-542 (2009).

51. Butler MS, Natural products to drugs: natural product-derived compounds in clinical trials. Natural product reports 25:475-516 (2008).

52. Katz L and Ashley GW, Translation and protein synthesis: macrolides. Chemical reviews 105:499-528 (2005).

53. $\mathrm{CH}$ C, Vitamin B6 (Pyridoxine; Pyridoxal 5'-Phosphate). (2001).

54. Kark JA, Kale MP, Tarassoff PG, Woods M and Lessin LS, Inhibition of erythrocyte sickling in vitro by pyridoxal. The Journal of clinical investigation 62:888-891 (1978).

55. Natta CL and Reynolds RD, Apparent vitamin B6 deficiency in sickle cell anemia. The American journal of clinical nutrition 40:235-239 (1984).

56. Ryan-Harshman M and Aldoori W, Carpal tunnel syndrome and vitamin B6. Canadian Family Physician 53:1161-1162 (2007).

This article is protected by copyright. All rights reserved. 


\section{Figure legends}

Figure 1: Comparison of growth curve of S. cerevisiae var boulardii NCYC 3264 (Sb) and S. cerevisiae BY4742 (Sc) under normal laboratory and simulated in vivo conditions considering temperature and oxygen availability (Only the first 750 min were fitted due to the decline in optical density after this time in some cultures)

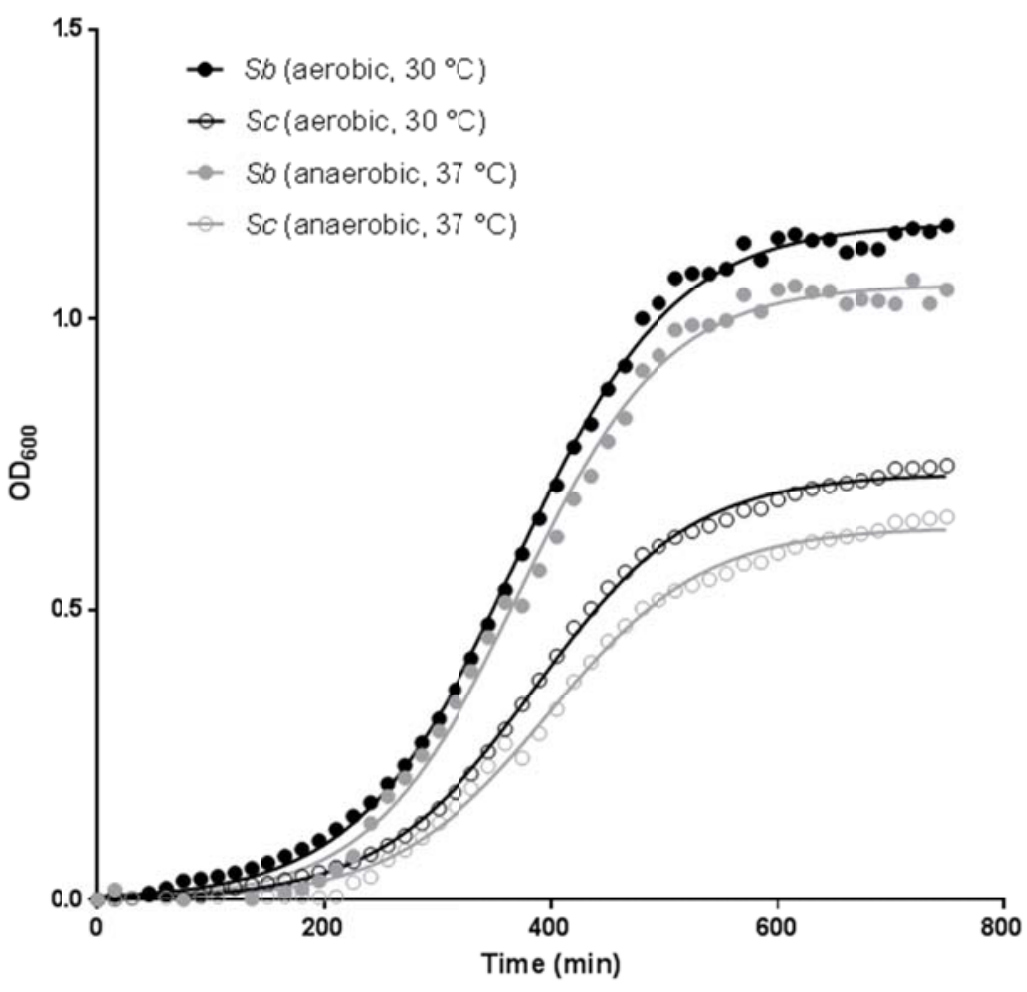

This article is protected by copyright. All rights reserved. 
Figure 2: Percentage cell viability of S. cerevisiae var. boulardii NCYC 3264 (black) and S. cerevisiae BY4742 (grey) as a response to heat stress and tolerance to simulated gastric and intestinal conditions $(\mathrm{T}=$ Temperature $)$.


Simulated gastric condition**

$\mathrm{T}=39^{\circ} \mathrm{C}^{* *}$

$\mathrm{T}=45^{\circ} \mathrm{C}^{*}$
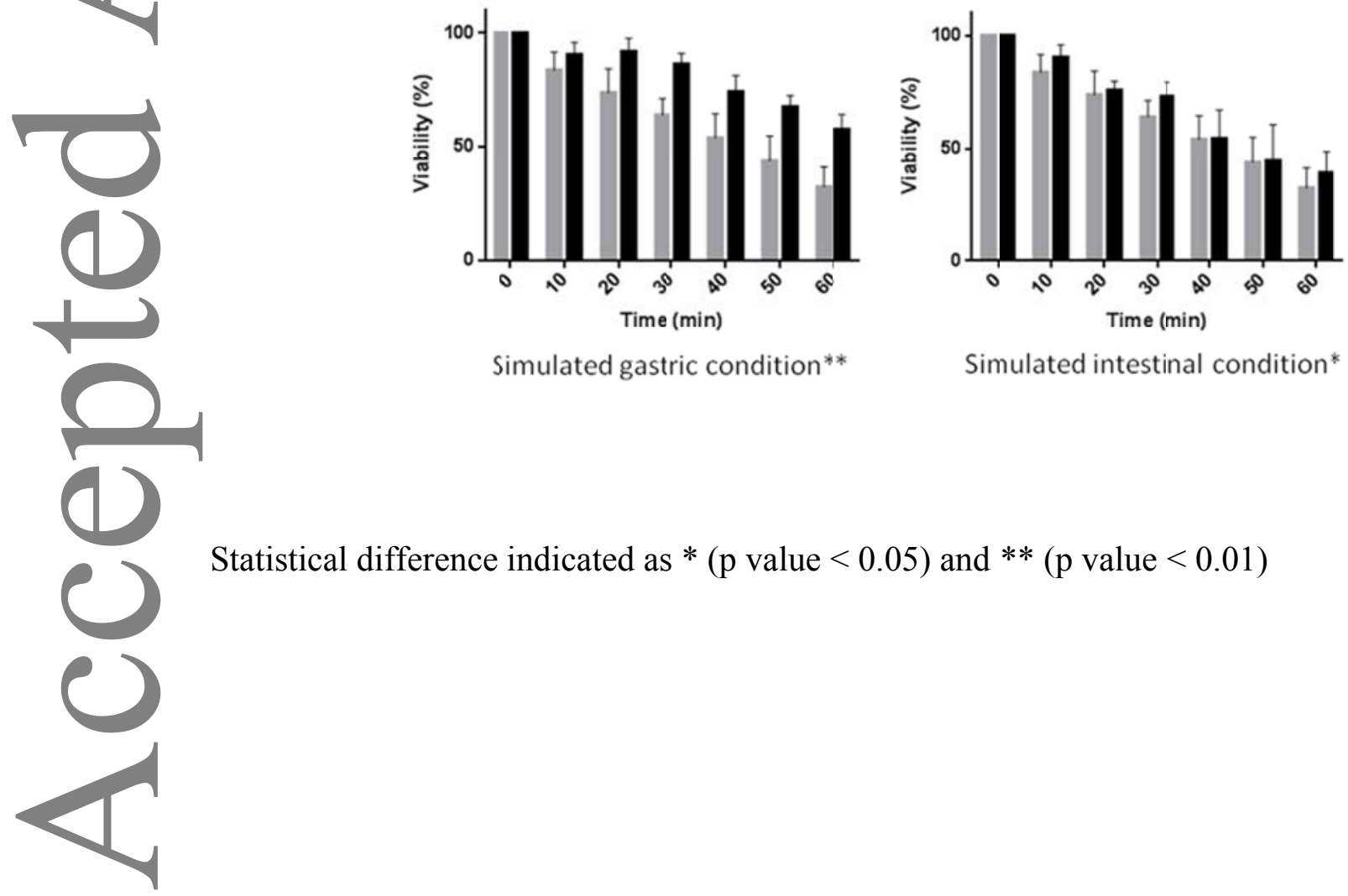

Simulated intestinal condition*

Statistical difference indicated as $*(\mathrm{p}$ value $<0.05)$ and $* *(\mathrm{p}$ value $<0.01)$

This article is protected by copyright. All rights reserved. 
Figure 3: Spot assay for viability on agar media containing different concentrations of bile salts at different temperatures. Sb - S. cerevisiae var boulardii NCYC3264; Sc - S. cerevisiae BY4742

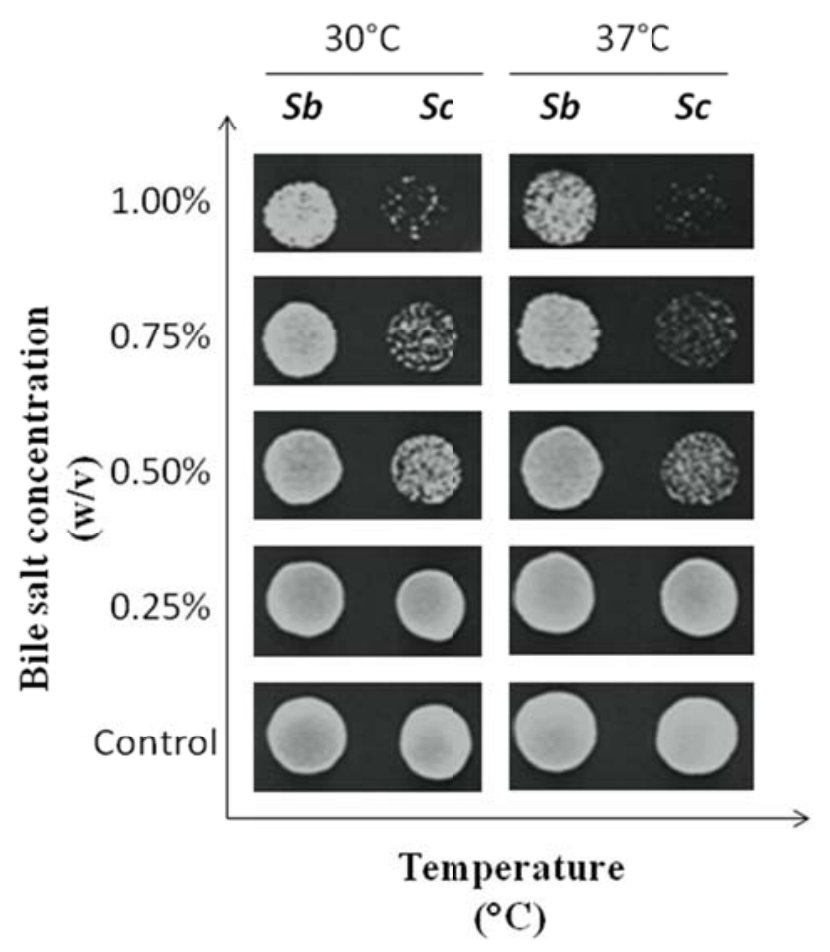

This article is protected by copyright. All rights reserved. 
Table1. Comparison of maximum specific growth rates $(\mathrm{k})$, optimum doubling times $\left(\mathrm{t}_{\mathrm{d}}\right)$ and maximum optical density $\left(\mathrm{OD}_{\max }\right)$ of microwell cultures under different conditions.

-

\begin{tabular}{|c|c|c|c|c|c|c|}
\hline \multirow[t]{2}{*}{ Strain } & \multicolumn{3}{|c|}{$\begin{array}{l}\text { Laboratory conditions } \\
\left.\text { (Aerobic, } 30^{\circ} \mathrm{C}\right)\end{array}$} & \multicolumn{3}{|c|}{$\begin{array}{l}\text { Simulated in vivo conditions } \\
\left.\text { (Anaerobic, } 37^{\circ} \mathrm{C}\right)\end{array}$} \\
\hline & $k\left(\min ^{-1}\right)$ & $t_{d}(\min )$ & $\mathbf{O D}_{\max }$ & $k\left(\min ^{-1}\right)$ & $t_{d}(\min )$ & $\mathbf{O D}_{\max }$ \\
\hline cerevisiae var. boulardii (NCYC 3264) & $0.0142 \pm 0.0003$ & 48.81 & $1.1660 \pm 0.0066$ & $0.0152 \pm 0.0004$ & 45.60 & $1.0590 \pm 0.0072$ \\
\hline S. çerevisiae S288C (BY4742) & $0.0143 \pm 0.0004$ & 48.47 & $0.7349 \pm 0.0056^{*}$ & $0.0145 \pm 0.0005$ & 48.80 & $0.6421 \pm 0.0062 *$ \\
\hline
\end{tabular}

Values of $\mathrm{k}$ and $\mathrm{OD}_{\max }$ were determined using non-linear curve fitting (see Materials and Methods). Only the first 750 min were fitted due to the decline in optical density after this time in some cultures.

*Statistically significantly different $(\mathrm{p}<0.05)$

This article is protected by copyright. All rights reserved. 
Table 2. Comparison of antioxidant properties of S. cerevisiae var.boulardii (NCYC 3264) and S. cerevisiae S288C (BY4742).

\begin{tabular}{lcccc}
\hline \multicolumn{1}{c}{ Activity } & \multicolumn{2}{c}{ S. cerevisiae var.boulardii (NCYC 3264) } & \multicolumn{2}{c}{ S. cerevisiae S288C (BY4742) } \\
\cline { 2 - 4 } & Cell-free extract & Ethyl acetate fraction & Cell-free extract & Ethyl acetate fraction \\
\hline TPC $\left(\mathrm{mg} \mathrm{GAE.g}^{-1}\right)$ & $7.11 \pm 0.30$ & $7.05 \pm 0.25$ & $0.14 \pm 0.05^{*}$ & $0.06 \pm 0.08^{*}$ \\
TFC $\left(\mathrm{mg}\right.$ QE. $\left.\mathrm{g}^{-1}\right)$ & $0.10 \pm 0.04$ & $0.11 \pm 0.20$ & $0.006 \pm 0.004^{*}$ & $0.004 \pm 0.006^{*}$ \\
DPPH assay $(\%$ & $33.16 \pm 0.11$ & $28.49 \pm 0.20$ & $5.28 \pm 0.30^{*}$ & $3.62 \pm 0.41^{*}$ \\
Inhibition $)$ & $141.89 \pm 0.22$ & $144.86 \pm 0.31$ & $-{ }^{\text {a }}$ & $-{ }^{\text {a }}$ \\
TEAC $(\mu M)$ & & & & \\
\hline
\end{tabular}

${ }^{\mathrm{a}}$ No detectable activity

${ }^{*}$ Statistically significantly different $(\mathrm{p}<0.05)$ from S. cerevisiae var.boulardii $($ NCYC 3264)

TPC, total phenolic content; TFC, total flavonoid content; DPPH, scavenging activity of 1,1diphenyl-2-picrylhydrazyl, TEAC, trolox equivalent antioxidant capacity assay. For assay conditions etc, see Materials and Methods.

This article is protected by copyright. All rights reserved. 
Table 4. List of metabolites identified by GC-MS in the extracellular and intracellular fraction of (a) S.cerevisiae var boulardii NCYC 3264 and (b) S. cerevisiae BY4742 culture. $\mathrm{R}_{\mathrm{t}}=$ retention time in min, MCF $=$ Methyl chloroformate, $\mathrm{m} / \mathrm{z}=\mathrm{mass}$ to charge ratio of target ion in the spectrum

(a)

\begin{tabular}{|c|c|c|c|c|c|c|c|c|}
\hline \multirow{2}{*}{$\begin{array}{c}\text { Peak } \\
\text { no. }\end{array}$} & \multicolumn{4}{|c|}{ Extracellular fraction } & \multicolumn{4}{|c|}{ Intracellular fraction } \\
\hline & $\begin{array}{c}\mathbf{R}_{\mathrm{t}} \\
(\mathrm{min})\end{array}$ & Metabolite & MCF derivatives & $\begin{array}{c}\mathrm{m} / \mathbf{z} \\
\text { (a.m.u) }\end{array}$ & $\begin{array}{c}\mathrm{R}_{\mathrm{t}} \\
(\mathrm{min})\end{array}$ & Metabolite & MCF derivatives & $\begin{array}{c}\mathrm{m} / \mathbf{z} \\
\text { (a.m.u) }\end{array}$ \\
\hline 1. & 8.902 & Succinic acid & Dimethyl ester & 146 & 8.915 & Succinic acid & Dimethyl ester & 146 \\
\hline 2. & 9.222 & D-glucose & $\begin{array}{c}\text { 2,3,6-tri-o-methyl } \\
\text { ester }\end{array}$ & 222 & 10.786 & L-alanine & $\begin{array}{c}N \text { - } \\
\text { methoxycarbonyl- } \\
\text { ethyl ester }\end{array}$ & 175 \\
\hline 3. & 9.427 & 1,3-dioxolane & $\begin{array}{l}\text { 2-methoxymethyl- } \\
\text { 2,4,5-trimethyl-ester }\end{array}$ & 160 & 11.782 & Hydroxylamine & - & 173 \\
\hline 4. & 10.446 & $\begin{array}{l}\text { Phenyl ethyl alcohol } \\
\text { (rose oil) }\end{array}$ & - & 122 & 12.615 & M-cymene & Methyl ester & 190 \\
\hline 5. & 10.594 & Amphetamine & $\begin{array}{l}N \text {-methoxy carbonyl } \\
\text { ester }\end{array}$ & 193 & 13.992 & L-leucylglycine & $\begin{array}{c}N- \\
\text { methoxycarbonyl- } \\
\text { methyl ester }\end{array}$ & 260 \\
\hline 6. & 10.937 & 2-pentenoic acid & 4-methyl- ester & 128 & 14.315 & L-phenylisoquinoline & - & 205 \\
\hline 7. & 11.477 & $\begin{array}{l}\text { Benzeneacetic acid } \\
\text { (mephaneine) }\end{array}$ & 4-methyl ester & 150 & 14.757 & L-proline & $\begin{array}{c}\mathrm{N}- \\
\text { methoxycarbonyl- } \\
\text { ester }\end{array}$ & 257 \\
\hline 8. & 12.621 & M-cymene & Methyl ester & 190 & 14.773 & D-proline, & $\begin{array}{c}N \text { - } \\
\text { methoxycarbonyl- } \\
\text { ester }\end{array}$ & 187 \\
\hline 9. & 13.095 & $\begin{array}{c}\text { Hydroxycinnamic } \\
\text { acid }\end{array}$ & Methyl ester & 164 & 14.888 & Hydroxylamine & - & 173 \\
\hline 10. & 13.992 & L-leucylglycine & $\begin{array}{l}N \text {-methoxycarbonyl- } \\
\text { methyl ester }\end{array}$ & 260 & 15.495 & DL-aspartic acid & $\begin{array}{c}N \text {-acetyl-dimethyl } \\
\text { ester }\end{array}$ & 203 \\
\hline
\end{tabular}

This article is protected by copyright. All rights reserved. 


\begin{tabular}{|c|c|c|c|c|c|c|c|c|}
\hline \multirow[t]{2}{*}{ Peak no. } & \multicolumn{4}{|c|}{ Extracellular fraction } & \multicolumn{4}{|c|}{ Intracellular fraction } \\
\hline & $\mathbf{R}_{\mathrm{t}}(\mathrm{min})$ & Metabolite & MCF derivatives & m/z (a.m.u) & $\mathbf{R}_{\mathrm{t}}(\mathrm{min})$ & Metabolite & MCF derivatives & m/z (a.m.u) \\
\hline 1. & 12.102 & D-glucose & Dimethyl ester & 146 & 16.206 & Pyruvic acid & Methyl ester & 174 \\
\hline 2. & 15.805 & Citric acid & Trimethyl ester & 234 & 18.932 & L-alanine & Dimethyl ester & 116 \\
\hline 3. & 16.113 & Lactic acid & Dimethyl ester & 191 & 22.265 & Valine & Dimethyl ester & 144 \\
\hline 4. & 23.952 & Succinic acid & tetramethyl ester & 247 & 23.704 & Ethanolamine & Dimethyl ester & 174 \\
\hline 5. & 24.062 & Glycerol & Trimethyl ester & 218 & 23.986 & Isoleucine/leucine & Dimethyl ester & 158 \\
\hline 6. & 25.982 & Fumaric acid & Dimethyl ester & 245 & 24.068 & Glycerol & Trimethyl ester & 218 \\
\hline 7. & 27.624 & Malic acid & Trimethyl ester & 233 & 25.034 & Glycine & Dimethyl ester & 102 \\
\hline 8. & & & & & 25.1 & Succinic acid & tetramethyl ester & 247 \\
\hline 9. & & & & & 25.817 & Uracil & Dimethyl ester & 241 \\
\hline 10. & & & & & 26.135 & Fumaric acid & Dimethyl ester & 245 \\
\hline 11. & & & & & 26.243 & Serine & Trimethyl ester & 204 \\
\hline 12 . & & & & & 26.992 & Threonine & Trimethyl ester & 218 \\
\hline 13. & & & & & 28.647 & Homoserine & Trimethyl ester & 218 \\
\hline 14. & & & & & 29.613 & Malic acid & Trimethyl ester & 233 \\
\hline \multirow{2}{*}{\multicolumn{5}{|c|}{$\begin{array}{l}15 . \\
\text { This article is protected by copyright. All rights reserved. } \\
16 .\end{array}$}} & 30.004 & Erythritol & 4-methyl ester & 217 \\
\hline & & & & & 30.092 & Cytosine & Dimethyl ester & 254 \\
\hline 17. & & & & & 30.501 & Aspartate & Trimethyl ester & 218 \\
\hline
\end{tabular}




\begin{tabular}{|c|c|c|c|c|}
\hline 18. & 31.906 & A-ketoglutaric acid & Dimethyl ester & 198 \\
\hline 19. & 32.903 & Glutamate & Trimethyl ester & 246 \\
\hline 20. & 33.102 & Phenylalanine & Dimethyl ester & 192 \\
\hline 21. & 33.419 & Ribose & 4-methyl ester & 217 \\
\hline 22. & 33.902 & Asparagine & Trimethyl ester & 231 \\
\hline 23. & 35.264 & 2-aminoadipic acid & Trimethyl ester & 260 \\
\hline 24. & 35.802 & Orotic acid & Trimethyl ester & 254 \\
\hline 25. & 36.051 & Glycerol-1-phosphate & 4-methyl ester & 370 \\
\hline 26. & 36.452 & Glutamine & Trimethyl ester & 156 \\
\hline 27. & 36.742 & $\mathrm{~N}$-acetyl-glutamic acid & Dimethyl ester & 216 \\
\hline 28. & 37.312 & Citric acid & 4-methyl ester & 273 \\
\hline 29. & 37.506 & Ornithine & 4-methyl ester & 258 \\
\hline 30. & 39.311 & Lysine & 4-methyl ester & 230 \\
\hline 31. & 39.842 & Mannitol & Hexamethyl ester & 307 \\
\hline 32. & 40.002 & Tyrosine & Trimethyl ester & 218 \\
\hline 33. & 42.946 & Inositol & Hexamethyl ester & 305 \\
\hline 34. & 43.005 & Xylulose-5-phosphate & 5-methyl ester & 315 \\
\hline 35. & 46.821 & Glucose-6-phosphate & Hexamethyl ester & 387 \\
\hline
\end{tabular}

This article is protected by copyright. All rights reserved. 


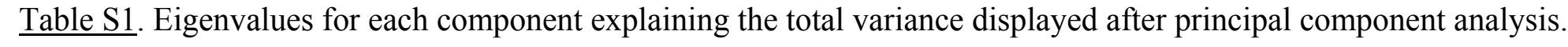

\begin{tabular}{|c|c|c|c|c|c|c|c|c|c|}
\hline \multirow{2}{*}{ Component } & \multicolumn{3}{|c|}{ Initial Eigenvalues } & \multicolumn{3}{|c|}{ Extraction Sums of Squared Loadings } & \multicolumn{3}{|c|}{ Rotation Sums of Squared Loadings } \\
\hline & Total & $\begin{array}{c}\% \text { of } \\
\text { Variance }\end{array}$ & $\begin{array}{c}\text { Cumulative } \\
\%\end{array}$ & Total & $\begin{array}{c}\text { \% of } \\
\text { Variance }\end{array}$ & $\begin{array}{c}\text { Cumulative } \\
\%\end{array}$ & Total & $\begin{array}{c}\text { \% of } \\
\text { Variance }\end{array}$ & $\begin{array}{c}\text { Cumulative } \\
\%\end{array}$ \\
\hline 1 & 8.098 & 73.619 & 73.619 & 8.098 & 73.619 & 73.619 & 7.866 & 71.513 & 71.513 \\
\hline 2 & 2.128 & 19.349 & 92.968 & 2.128 & 19.349 & 92.968 & 2.360 & 21.455 & 92.968 \\
\hline 3 & .774 & 7.032 & 100.000 & & & & & & \\
\hline 4 & $3.739 \mathrm{E}-016$ & $3.399 \mathrm{E}-015$ & 100.000 & & & & & & \\
\hline 5 & $2.486 \mathrm{E}-016$ & $2.260 \mathrm{E}-015$ & 100.000 & & & & & & \\
\hline 6 & $9.181 \mathrm{E}-017$ & $8.347 \mathrm{E}-016$ & 100.000 & & & & & & \\
\hline 7 & $8.614 \mathrm{E}-017$ & $7.830 \mathrm{E}-016$ & 100.000 & & & & & & \\
\hline 8 & $1.653 \mathrm{E}-018$ & $1.502 \mathrm{E}-017$ & 100.000 & & & & & & \\
\hline 9 & $-1.134 \mathrm{E}-016$ & $-1.031 \mathrm{E}-015$ & 100.000 & & & & & & \\
\hline 10 & $-2.253 \mathrm{E}-016$ & $-2.048 \mathrm{E}-015$ & 100.000 & & & & & & \\
\hline 11 & $-4.340 \mathrm{E}-016$ & $-3.946 \mathrm{E}-015$ & 100.000 & & & & & & \\
\hline
\end{tabular}

This article is protected by copyright. All rights reserved. 